American Journal of Agricultural and Biological Sciences 4 (3): 201-205, 2009

ISSN 1557-4989

(C) 2009 Science Publications

\title{
Structure, Ultrastructure of the Anther, Pollen Microsporogenesis and Morphology of Pollen Grains of Two Populations of Lygeum spartum L. in Algeria
}

\author{
Katia Abdeddaim-Boughanmi and Meriem Kaid-Harche \\ Department of Biotechnology, Sciences Faculty, University of Science and Technology, \\ Mohamed Boudiaf, P.O. Box. 1505, El Mnaouar, Oran, 31000, Algeria
}

\begin{abstract}
Problem statement: The Lygeum spartum L. represented by a single species occupies several regions of the Mediterranean basin. This plant plays an important ecological role in the fight against desertification and economic development in the manufacture of paper pulp. Approach: However, the cytogenetic studies in mitosis in this species revealed the existence of two ploidy levels: $2 n=40$ among the population grows in the coastal region of Oran in the semi-arid climate and $2 n=16$ in the high plateaus characterized by an arid climate. Results: The study of the anther, pollen grains and the meiotic division conducted on these two populations of Lygeum spartum L. growing in the two regions has confirmed these data in that the microscopic observations were used to determine the ultrastructure of the anther, the shape and size of pollen grains which morphometric data $(\mathrm{L} / \mathrm{W})$ showed significant difference between the two populations. The microsporogenesis was followed on the mother cells of pollen grains in order to understand the formation of tetrads, then the enumeration of chromosomes was carried out in diakinesis $(\mathrm{n}=20)$ for the coastal population of Oran and metaphase $\mathrm{I}(\mathrm{n}=8)$ for the population of the high plateaus. Conclusion/Recommendations: These results were consistent with what has been observed in mitosis, which suggested that the Lygeum spartum L. may submit two cytotypes to adapt to different geographical and climatic environments.
\end{abstract}

Key words: Lygeum spartum L., pollen grains, morphology, anther ultrastructure, meiosis

\section{INTRODUCTION}

Lygeum genus represented by a single species: Lygeum spartum is characterized ${ }^{[1]}$ by a creeping rhizome, cylindrical and squalid leaves. The stems are terminated by a large spathe containing 1-4 flowers, each of them is consisting of 3 stamens and 1 pistil. The Lygeum spartum $\mathrm{L}$. is a perennial grass (Poaceae) of the Mediterranean basin ${ }^{[2]}$, which colonizes the skeletal soils to limestone or gypsum crust ${ }^{[3]}$.

Regarding to its ecological interest in preventing desertification by stabilizing sand ${ }^{[4]}$ and its economic interest of obtaining paper pulp from foliar tissues ${ }^{[5]}$. Lygeum spartum L. is an interesting plant to operate and develop in the context of sustainable development. Various works related to the germination and the study of the fructification capacity of spikelets ${ }^{[6,7]}$. The cytogenetic study of two populations of Lygeum spartum L. were also made ${ }^{[8]}$.

Knowledge of the flower and the structure of reproductive organs of this species are poorly understood. This work which is within the subject of biodiversity conservation of the species in arid Algerian regions concerns the ultrastructure of the anther, the pollen microsporogenesis and pollen grain morphology of two populations of Lygeum spartum L.

\section{MATERIALS AND METHODS}

Plant material: The used materials are inflorescences of Lygeum spartum L. collected from two different stations: one is located in the Oran region in the region of Es-Sénia near the sebkha at latitude $35^{\circ} 38^{\prime} \mathrm{N}$, longitude $00^{\circ} 36 \mathrm{~W}$ and an altitude of $90 \mathrm{~m}$; this station is characterized by a semi-arid climate. The second station with arid climate is in the region of El-Kheiter in the high plateaus of south-western Algeria at latitude $34^{\circ} 09^{\prime} \mathrm{N}$, longitude $00^{\circ} 04^{\prime} \mathrm{W}$ and an altitude of $1000 \mathrm{~m}$.

\section{Methods:}

Morphological techniques:

Structure and ultrastructure of the anther: Inflorescences were collected, their spathes were manually opened to release the anthers. These are cut

Corresponding Author: Katia Abdeddaim-Boughanmi, Department of Biotechnology, Faculty of Sciences,

University of Science and Technology, Mohamed Boudiaf, P.O. Box. 1505, El Mnaouar, Oran, 31000, Algeria Tel: 00213775601252 
with a razor blade into segments of 3-5 $\mathrm{mm}$ and then fixed for $1 \mathrm{~h} 30 \mathrm{~min}$ in $3 \%$ glutaraldehyde in $0.05 \mathrm{M}$ sodium cacodylate buffer at $\mathrm{pH}$ 7.4. After a wash in the same buffer, samples were also post-fixed for $1 \mathrm{~h}$ at room temperature in $1 \%$ osmium tetroxide in cacodylate buffer, dehydration is performed by passing through ethanol baths with croissant degrees. Embedding were made in Araldite $\operatorname{resin}^{[9]}$. After polymerization the obtained blocks are cut off. Then semi-thin sections, 1-2 $\mu \mathrm{m}$ thick were made and stained with toluidine blue and observed by photonic microscope.

Ultra-thin sections $600-800 \AA$ thick are made up, mounted on gold grids of 400 mesh and contrasted with uranyl acetate-lead citrate ${ }^{[10]}$ to reveal the contents of cytoplasmic pollen sac .The test PATAg (periodic acid, thiocarbohydrazide, silver proteinate $)^{[11]}$ which highlights the parietal polysaccharides with vic-glycols radicals is carried out on ultra-thin sections mounted on gold grids of 300 mesh. The observations were made by a transmission electronic microscope.

Morphology of pollen grains: The morphology of pollen grains was determined by examining samples dehydrated, under a scanning electron microscope, after gold metallization to a thickness of $300 \AA$.

Morphometry of pollen grains: In order to determine the size of pollen grains of Lygeum spartum L., measures have been carried out on 30 flowers taken from 30 tufts for both considered stations. To do this the pollen of mature anthers is deposited on a glass slide in a drop of distilled water and then covered with a coverslip, the pollen grains are released and measured (Length (L) and Width (W)) with a micrometer incorporated into the photonic microscope of Leitz type. Statistical analysis is then made using the ANOVA test at the risk $\alpha=0.05$.

Study of microsporogenesis pollen: Young anthers were collected and fixed in CarnoyI ${ }^{[14]}$ for $24 \mathrm{~h}$, the samples were then hydrolyzed in $\mathrm{HCl} 1 \mathrm{~N}$ at $60^{\circ} \mathrm{C}$ for $10 \mathrm{~min}$ and then stained with acetic carmine ${ }^{[12]}$ and mounted between slide and cover-slip in a drop of $45 \%$ acetic acid, here a slight pressure is exerted to promote the dispersion of cells. Stages of meiosis were observed and photographed with a photomicroscope of Zeiss type.

\section{RESULTS}

Structure and ultrastructure of the anther: The semithin sections show that the anther of Lygeum spartum L. has a similar structure to that of the anthers of angiosperms already described ${ }^{[13]}$. We observe two pollen loculi and four pollen sacs connected by the connective at the centre of which a vascular bundle is surrounded by parenchymatous tissue (Fig. 1).

The pollen sac is formed by the epidermis, consisting of a layer of cells joined with thin walls, it is covered by the endothecium is formed by elongated cells 2-3 times the size of epidermal cells. The middle layer is composed of flattened and tapered cells; the tapetum forming the internal layer consists of cubical cells recalling the meristematic cells in dense cytoplasm and large nucleus. Some cells are binucleate (Fig. 2).

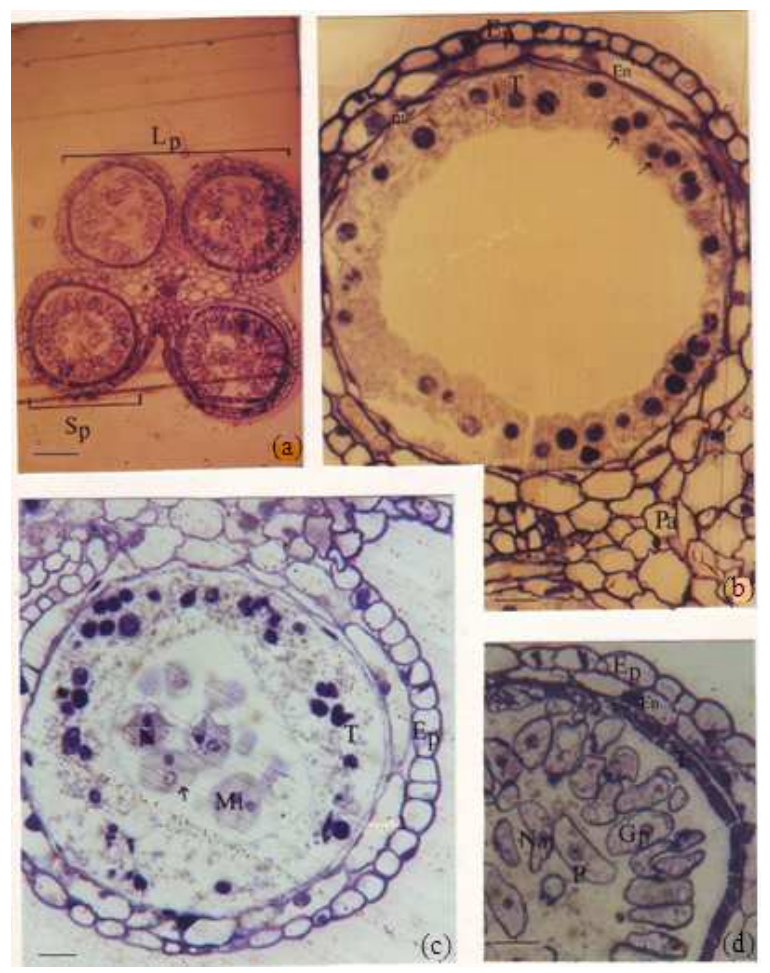

Fig. 1: (a): Overview of the anther of Lygeum spartum L. X330; (b): Detail of the pollen sac X2100. Note the binucleate state of tapetum cells (arrows); (c): Pollen sac containing microspores at diade stage (arrow) and disruption of the tapetum cells. X2100; (d): Pollen sac containing mature pollen grains. X2100. Legends: En: Endothecium, Ep: Epidermis, Gp: Pollen grains, Lp: Loculus pollen, Mi: Microspore, mL: Middle layer, N: Nucleus, n: Nucleolus, P: Pore, Pa: Parenchyma, Sp: Pollen sac, T: Tapetum. The bar in micrographs represents: $30 \mu \mathrm{m}$ (Fig. 1); $0.5 \mu \mathrm{m}$ (Fig. a-d) 

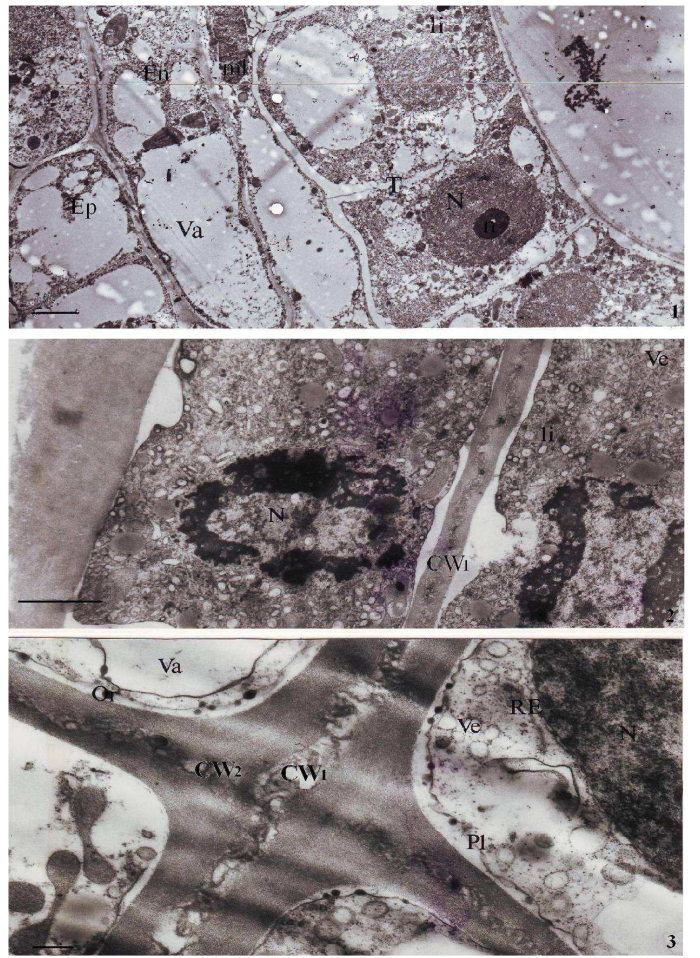

Fig. 2: (a): Ultrastructure of pollen sac. x15000; (b): Ultrastructure of a diade. x8580; (c): Ultrastructure of a tetrad. X23240. Legends: CW1: Cell wall1; CW2: Cell wall2. En: Endothecium; Ep: Epidermis; li: Lipid; mL: Middle layer; N: Nucleus; Or: Orbicules; Pl: Plasma Membrane; RE: Endoplasmic Reticulum; T: Tapetum; Va: Vacuole; Ve: Vesicles. The bar on micrographs represents: (a); $10 \mu \mathrm{m}$; (b); $2.5 \mu \mathrm{m}$; (c): $0.5 \mu \mathrm{m}$

At a later stage, cells have a disruption with no walls (Fig. 3), these cells are the source of spore cells. The pollen sac is occupied by the mother cells of pollen gains at diade stage. The observation of a section of a mature anther shows a pollen sac containing differenciate pollen grains (Fig. 4).

The ultrastructural observation of the anther confirms the organization of the pollen sac seen on semi-thin sections (Fig. 2a).

The mother cells of pollen grains ultrastructure shows that they are at diade stage (Fig. 2b). The tetrad is distinguishing after deposit of a second cell wall (Fig. 2c). The tetrad have a dense cytoplasm, numerous vacuoles, free and abundant ribosomes, mitochondria, numerous vesicles and lipid droplets (Fig. 2c). The plasma membrane presents an irregular contour where concentrate granules osmiophile deposit (Fig. 2c) which remember the orbicules of Ubish.

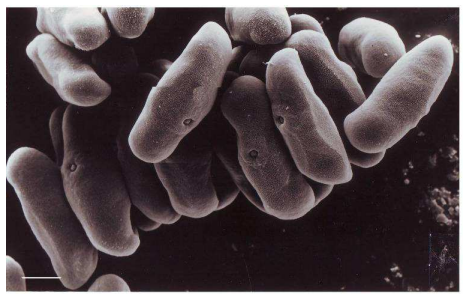

(a)

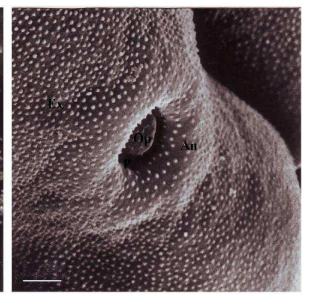

(b)
Fig. 3: (a): Overview of pollen grains of Lygeum spartum L. x240; (b): Detail of the exine and the aperture of pollen grains. x800. Legends: an: Annulus; Ex: Exine; Op: Operculum; P: Pore. The bar on micrograhs represents: (a); $50 \mu \mathrm{m}$; (b): $20 \mu \mathrm{m}$
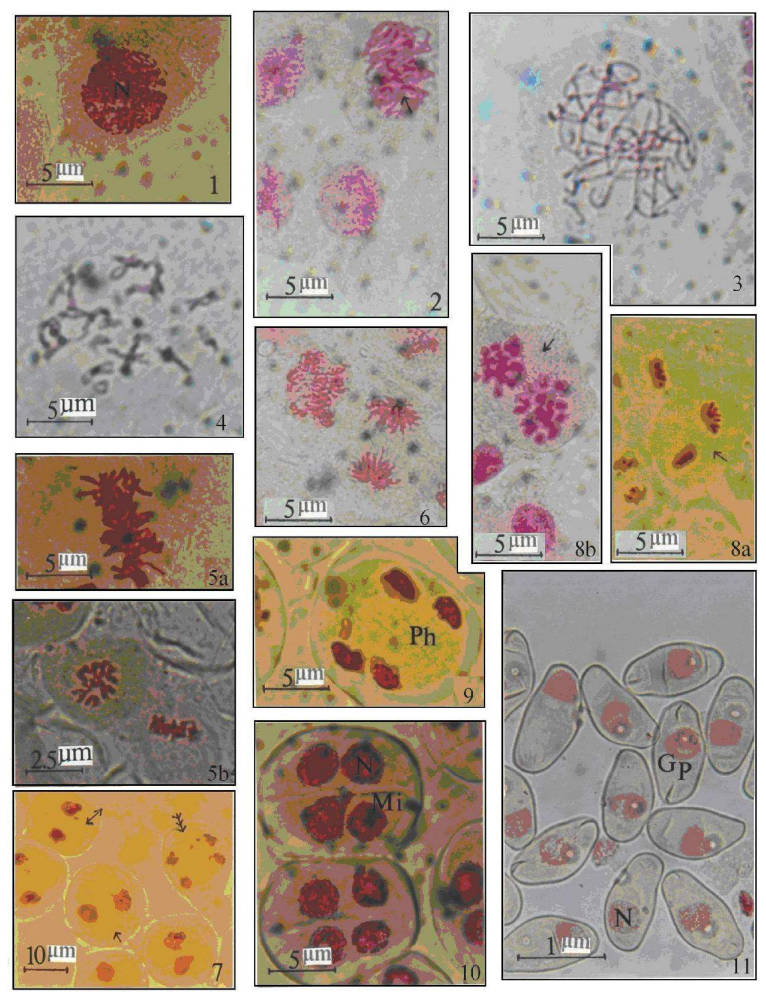

Fig. 4: (1): Pre-meiotic stage. x3360. (2): Leptotène. x3360. (3): Pachytene. x3360. (4): diakinesis. x3360. (5a and b): Metaphase I (polar and equatorial plate). x3360. (6): Anaphase I. x3360. (7): telophase I (double arrows) and anaphase II (triple arrows) indicating the presence of a chromosome B. x1344. (8a and b): Metaphase II (polar and equatorial plate). x1344. (9): Telophase II. x3360. (10): Tetrade. x3360. (11): Mature pollen grains. x2100. Legends: Gp: Pollen grains, Mi: Microspore, $\mathrm{N}$ : Nucleus, Ph: phragmoplaste 
Table 1: Morphometric data of pollen grains of two populations of Lygeum spartum $\mathrm{L}$

\begin{tabular}{llll}
\hline Station & Length $(\mathrm{L})(\mu \mathrm{m})$ & Width $(\mathrm{W})(\mu \mathrm{m})$ & Ratio $(\mathrm{L} / \mathrm{W})$ \\
\hline El-Kheiter & $68,82 \pm 4,26$ & $28,08 \pm 1,8$ & $2,45 \pm 0,16$ \\
Sebkha & $63,96 \pm 7,86$ & $26,73 \pm 3,06$ & $2,40 \pm 0,28$ \\
\hline
\end{tabular}

Morphology of pollen grains: A scanning electron microscope observations show that pollen grains of Lygeum spartum L. are ovoid with rounded poles (Fig. 3a). The aperture present an unique pore surrounded by a distinct thickening called annulus. This pore is covered by a membrane called the operculum. The tectale surface or exine is a granular type (Fig. 3b).

The morphometric data show (Table 1) that the size of pollen grains of the population growing in the high-plateaus (El-Kheiter) is significantly greater than the coast of Oran (Sebkha). The difference of ratio L/W between the two stations could be indication of differentiation between pollens of both populations.

Pollen microsporogenesis: The study of meiotic behavior has followed all the stages until the formation of pollen grains with no specific abnormalities (Fig. 4). At telophase I and anaphase II stages, we note the existence of a chromosome that does not migrate to one of two poles, it is the chromosome B (Fig. 4(7)).

The chromosome number, conducted respectively in diakinesis and metaphase $\mathrm{I}$ is $\mathrm{n}=20$ in mother cells of pollen grains in the coastal population of Oran (Sebkha) (Fig. 4(5a)) and $n=8$ in the population of the high-plateaus (El-Kheiter) (Fig. 4(5b)).

\section{DISCUSSION}

The histological study of the anther of Lygeum spartum L. is similar to what has been described in angiosperms ${ }^{[15-17]}$ with the exception of the binucleate state cells of tapetum which are seems present also in Monocots. This feature was reported only in eudicots ${ }^{[18]}$. The anther of Lygeum spartum L. is characterized by the presence of a secretory tapetum. The secreted substances are probably involved in the growth of microspores ${ }^{[17]}$ among Aristideae and in the development of the exine ${ }^{[19]}$. The presence of Ubisch body, precursor of sporopollenin, confirms that the tapetum of the anther Lygeum spartum L. is a secretory type. These orbicules are an argument for the participation of the tapetum in the development of the exine $^{[19]}$.

The ultrastructure of the tetrad, after successive divisions, shows that it is flat, this is a characteristic of Monocots ${ }^{[20]}$.
Pollen grains of Lygeum spartum L. differ from Poaceae by their more or less elongated form which is spherical and globular in monocots ${ }^{[21-23]}$ already described. The difference in size of pollen grains suggests that there is a varietal difference in relation to their origin ${ }^{[24]}$.

The stages of meiosis in the mother cells of pollen grains of Lygeum spartum L. is identical to what is usually described among plant species. The existence of the chromosome B observed in the coast oranian population could be related to the percentage of spikelets malformations ${ }^{[25]}$.

The number of chromosomes found in the haploid phase of the two populations $(n=8$ and $n=20$ ) corresponds to half $^{[8]}$ on the root apex. The existence of two ploidy levels: $2 \mathrm{n}=40$ in Sebkha region (coast of Oran) and $2 \mathrm{n}=16$ in Aïn Benkhelil (high-plateaus) is confirmed in this study et laisse suggérer l'existence de deux cytotypes.

\section{CONCLUSION}

Studies on the Lygeum spartum L. from both stations showed many differences: biochemical in parietal seed hairs composition ${ }^{[26]}$; morphological and fructification capacity of spikelets ${ }^{[25]}$. The significant difference in the ratio L/W between the pollen grains of two stations observed in this study is another parameter distinguishing the two populations. Studies using more refined techniques (cytogenetics molecular) should continue to better understand the phylogeny of Lygeum spartum $\mathrm{L}$.

\section{REFERENCES}

1. Quezel, P. and S. Santa, 1962. Nouvelle Flore de l'Algérie et des Régions Désertiques Méridionales. Tomes 1 et 2, CNRS, France, pp: 1170. http://www.cnrseditions.fr/ouvrage/3336.html

2. Hochreutiner, B. and Le Sud-Oranais, 1904. Etude floristique et phytogéographique. Ann. Conserv. Jord. Bot. Genève, 7-8: 23-276.

3. Le Houerou, H.N., 1995. Considérations biogéographiques sur les steppes arides du nord de l'Afrique. Sécheresse, 6: 167-182.

4. Aidoud, A., 1983. Contribution à l'étude des écosystèmes steppiques du sud-oranais (phytomasse, productivité primaire et application pastorales). Doct. 3ème cycle. Univ. Sci. Technol., USTHB. Alger, pp: 240.

5. Harche, M., R. Chadli and A.M. Catesson, 1990. Divesity of cellulose microfibril arrangement in the cell wallas of Lygeum spartum leaves. Ann. Bot., 65: 79-86.

http://aob.oxfordjournals.org/cgi/content/abstract/65/1/79 
6. Djabeur, A., 2007. Physiologie de la germination des caryopses de trois Poacées vivaces: Alfa (Stipa tenacissima L.), Sparte (Lygeum spartum L.) et Aristida (Aristida pungens Desf.). Polymorphisme morphologique, biochimique et moléculaire de quelques populations de Lygeum spartum L. Thèse Doct. Es Science. USTOMB, pp: 125.

7. Djabeur, A., M. Kaid-Harche and D. Khelifi, 2008. Proteins polymorphism of some populations of Lygeum spartum L. in Algeria. Am. J. Agric. Biol. Sci., 3: 337-341. http://www.scipub.org/fulltext/AJAB/AJAB31337341.pdf

8. Benmansour, N. and M. Kaid-Harche, 2001. Etude caryologique de deux populations de Lygeum spartum L. (Gramineae) de l'ouest algérien. Bocconea, 13: 371-376.

9. Glauert, A.M. and R.H. Glauert, 1958. Araldite is an embedding medium for electron microscopy. J. Biophys. Biochem. Cytol., 4: 167-174. http://www.pubmedcentral.nih.gov/articlerender.fc gi? artid=2224339

10. Reynolds, E.S., 1963. The use of lead citrate at high $\mathrm{pH}$ as an electron opaque stain in electron microscopy. J. Cell. Biol., 17: 208-212. http://www.pubmedcentral.nih.gov/articlerender.fc gi?artid=2106263

11. Thierry, J.P., 1967. Mise en évidence des polysaccharides sur des coupes fines en microscopie électronique. J. Microscopie, 6: 987-1018.

12. Gagnieu, A., 1946. Technique de dénombrement des chromosomes. Rev. Cyt. et Cytophysiol. Vég., 2: 243-246.

13. Roland, J.C. and F. Roland, 1989. Atlas de Biologie Végétale. 4th Edn., Organisation des Plantes à Fleurs. Masson et Cie, pp: 117.

14. Jahier, J., A.M. Chèvre, F. Eber, R. Delourme and A.M. Tanguy, 1992. Techniques de Cytogénétique Végétale. INRA Publisher, Paris, France, pp: 184.

15. Madjd, A. and F. Roland-Heydacker, 1978. Sécrétions et dégénérescence des cellules du tapis dans l'anthère du Soja hispida Moench, Papilionaceae. Grana, 17: 167-174. DOI: 10.1080/00173137809431962

http://www.informaworld.com/smpp/content $\sim \mathrm{db}=\mathrm{a}$ 1l content $=\mathrm{a} 914356085 \sim \mathrm{tab}=$ citations

16. Bandari, N.N., 1985. The Microsporangium. In: Embryology of Angiosperms, Jhori, B.M. (Ed.). Springer-Verlag, Heidelberg, ISBN: 0387127399, pp: 830 .
17. Febulaus, G.N.V. and T. Pullaiah, 1994. Embryology of Aristida (Poaceae). Taïwania, 38: 38-48.

18. Bouguedoura, N., L. Boughediri and N. Bounaga, 1990. Ontogénie et ultrastructure du pollen du palmier dattier, Phoenix dactylifera L. Bull. Soc. bot. Fr., 137, Actual. Bot., 2: 154-155.

19. Dunbar, A., 1973. Pollen development in the Eleocharis palustris group (Cyperaceae). Ultrastructure and ontogeny. Bot. Not., 126 : 197-254. http://kbd.kew.org/kbd/detailedresult.do?id=3599

20. Roland-Heydacker, F., $1979 . \quad$ Aspects ultrastructuraux de l'ontogénie du pollen et du tapis chez Mahonia aquifolium Nutt. Berberidaceae. Pollen et Spores, 3: 259-278.

21. Peltre, G., M.Th. Cerceau-Larrival, M. Hideux, M. Abadie and B. David, 1987. Scanning and Transmission electron microscopy related to immunochemical analysis of grass pollen. Grana, 26: $158-170$.

22. Cerceau-Larrival, M.Th., 1990. Le pollen: Gametophyte mâle. Bull. Soc. Bot. Fr. Actual. Bot., 1: 33-40.

23. Chaturvedi, M.D., Yunus and K. Datta, 1994. Pollen morphology of Sorghum Moench. Sections Eu-sorghum and Para-sorghum. Grana, 33: 117-123. http://direct.bl.uk/bld/PlaceOrder.do?UIN=01954555 $6 \& \mathrm{ETOC}=\mathrm{EN} \&$ from $=$ searchengine

24. Boughediri, L., 1985. Contribution à la connaissance du palmier dattier (Phoenix dactylifera L.) étude du pollen. Thèse de Magister. USTHB. Alger, pp: 130.

25. Djabeur, A., M. Kaid-Harche and A.M. Catesson, 2008. Fruit structure and fructification capacity of two cytotypes from western Algeria. Ecol. Mediterranea, 34: 5-11.

26. Zeriahène, N., R. Prat, R. Goldberg, A.M. Catesson and M. Kaid-Harche, 1998. Cell wall of seed hairs from Lygeum spartum: Ultrastructure, composition and mechanical properties. Ann. Bot., 81: 61-66. 